John Carroll University

Carroll Collected

English

6-1997

\title{
Fast Fish and Raw Fish: Moby-Dick, Japan, and Melville's Thematics of Geography
}

Russell Reising

Peter Kvidera

John Carroll University, pkvidera@jcu.edu

Follow this and additional works at: http://collected.jcu.edu/engl-facpub

Part of the English Language and Literature Commons

\section{Recommended Citation}

Reising, Russell and Kvidera, Peter, "Fast Fish and Raw Fish: Moby-Dick, Japan, and Melville's Thematics of Geography" (1997).

English. 5.

http://collected.jcu.edu/engl-facpub/5

This Article is brought to you for free and open access by Carroll Collected. It has been accepted for inclusion in English by an authorized administrator of Carroll Collected. For more information, please contact connell@jcu.edu. 


\section{Fast Fish and Raw Fish: Moby-Dick, Japan, and Melville's Thematics of Geography}

RUSSELL REISING AND PETER J. KVIDERA

If that double-bolted land, Japan, is ever to become hospitable it is the whale-ship alone to whom the credit will be due; for already she is on the threshold.

\section{-Moby-Dick}

The whole enterprise of this nation, which is not an upward, but a westward one, toward Oregon, California, Japan, etc. is totally devoid of interest to me whether performed on foot, or by a Pacific railroad. . . . It is perfectly heathenish,-a filibustering toward heaven by the great western route. . . . What end do they propose to themselves beyond Japan.

\section{- Henry David Thoreau to Harrison Blake,} 27 February 1853

$\mathrm{T}$ the waters off the coast of Japan, Captain Ahab first con1 fronts and is ultimately defeated by the great white whale. The siting of those epic events is no accident, nor is its naming casual. Indeed, in the course of his novel, Herman Melville creates an elaborate geo-tropics intended to bear the weight of his complicated thematic intentions. Navigating the narrative of Moby-Dick much as Ahab captains the Pequod, Ishmael, the text's narrator, maps both the ship's voyage and his own postPequod ramblings. Many locales fall within his ken-the Cape of Good Hope, Java Head, the Bashee Isles, the Arsacides, and Lima, Peru; he describes all and provides significant details about places such as Nantucket, whose population figures he offers and which he presents to readers for close scrutiny: "Look at it-a mere hillock, an elbow of sand; all beach, without a back- 
ground." $\mathrm{He}$ even examines Queequeg's Kokovoko, though not on any map, to discover its natural resources and social practices.

Venturing further than literal, cartographic references, however, Ishmael charges many of his narrative's locales with metaphoric significance. New Bedford, for example, no mere stopping point on Ishmael's journey, embodies the coldness of the Western civilization from which he periodically escapes. ${ }^{2}$ Similarly, Nantucket is not just the Pequod's home port but also the rocky grave of the legendary Indian infant abducted by an eagle, a metaphor that prompts Ishmael's sustained meditation on orphanhood. Beyond American shores, Tahiti springs from the Pacific, an image of calm against which Ishmael gauges the "tornadoed Atlantic" of his being. Indeed, the many islands scattered throughout the text geographically construct Ishmael's trope of isolation, a characteristic he shares with all who inhabit the text of Moby-Dick. And what links these various, geographic sites is their availability; the West's knowledge of them provides an archive upon which Ishmael can draw for his cartographic and metaphoric purposes.

Japan, however, differs from every other place named in Moby-Dick, for it remains largely unknown, and yet Ishmael refers to Japan, or to things Japanese, no fewer than twenty-one times (with several additional, indirect allusions). Those references invariably evoke the mystery and doom that haunts the narrative, but those qualities do not proceed solely from Ishmael's pen. Rather, Ishmael's Japan reflects his culture's attempt to enter, understand, and dominate the Asian island nation. Isolated and impenetrable for centuries, Japan was finally "opened" to the outside world on 3 March 1854, when the Tokugawa shogunate, persuaded by Matthew Perry's display of U.S. might

\footnotetext{
${ }^{1}$ Herman Melville, Moby-Dick; or, The Whale, ed. Harrison Hayford, Hershel Parker, and G. Thomas Tanselle, vol. 6 of The Writings of Herman Melville (Evanston: Northwestern University Press, 1988), p. 63. All subsequent references to this volume will be noted parenthetically.

${ }^{2}$ See Paul Brodtkorb, Jr.'s Ishmael's White World (New Haven: Yale University Press, 1965) and Bainard Cowan's remarkable Exiled Waters: Moby Dick and the Crisis of Allegory (Baton Rouge: Louisiana State University Press, 1982) for excellent readings of Ishmael's general state of mind and of the cultural milieu of coldness out of which he sails with Captain Ahab.
} 
and prestige, finally agreed to open its harbors. Four years earlier, as Melville wrote Moby-Dick, however, Japan remained largely unknowable to the author proudly familiar with much of the Pacific. It was during the years of the West's most intense campaign to "open up" Japan, economically for raw materials and commerce and politically for ongoing diplomatic relations, that Melville's "late consumptive usher to a grammar school," his "sub-sub-librarian," and Ishmael all gather information concerming the honor, glory, technologies, and history of whaling. Concluding his speculation concerning the magnetic intrigue of water, Ishmael decides, "surely all this is not without meaning" (p. 5). Neither, surely, is Melville's decision to structure Ahab's obsession with Moby Dick with special reference to Japan.

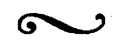

Having lost his leg to Moby Dick off Japan, Ahab redoubles the fierce intensity of his vengeful hunt as the Pequod nears the Japanese whaling grounds. Starbuck finds Ahab scouring two maps in his cabin, one a "general chart of the oriental archipelagoes" and the other a "separate one representing the long eastern coasts of the Japanese islands-Niphon, Matsmai, and Sikoke" (p. 473). When the mate interrupts Ahab to ask permission to "up Burtons and break out," Ahab rages, "Up Burtons and break out? Now that we are nearing Japan; heave-to here for a week to tinker a parcel of old hoops?" (p. 474). Ishmael is thrown into reflection:

Now, sometimes, in that Japanese sea, the days in summer are as freshets of effulgences. That unblinkingly vivid Japanese sun seems the blazing focus of the glassy ocean's immeasurable burning-glass. The sky looks lacquered; clouds there are none; the horizon floats; and this nakedness of unrelieved radiance is as the insufferable splendors of God's throne. [P. 500]

With descriptors like "lacquered," Ishmael japanizes his rendering of the scene. But his allusions range beyond traditional Japanese aesthetics to encompass the mythology of the land. Ahab and Fedallah are captured in a static moment of sun- 
worship, Ahab measuring the sun's position with his quadrant, the Asian "with face thrown up like Ahab's, ... eyeing the same sun with him" (p. 501). The tableau elicits, perhaps intentionally, the common designation of Japan as the land of the rising sun or, in a literal reading of the Japanese characters, the land of the sun's origin.

Even Ishmael's representation of the Pequod makes pointed reference to Japan:

You may have seen many a quaint craft in your day, for aught I know;-square-toed luggers; mountainous Japanese junks; butter-box galliots, and what not; but take my word for it, you never saw such a rare old craft as this same rare old Pequod. . . Long seasoned and weather-stained in the typhoons and calms of all four oceans, her old hull's complexion was darkened like a French grenadier's, who has alike fought in Egypt and Siberia. Her venerable bows looked bearded. Her masts - cut somewhere on the coast of Japan, where her original ones were lost overboard in a gale-her masts stood stiffly up like the spines of the three old kings of Cologne. Her ancient decks were worn and wrinkled, like the pilgrim-worshipped flag-stone in Canterbury Cathedral where Becket bled. ... She was apparelled like any barbaric Ethiopian emperor. [Pp. 69-70, emphasis added] ${ }^{3}$

Ishmael evokes the Pequod's exoticism by detailing its global stores-raw materials and ornaments from locations throughout the world. But as our emphasis of the word "like" suggests, Japan emerges in this brief description as the only locale directly named, not signified solely by metaphor.

Ishmael's references to Japan always emerge within the context of the tale's ultimate physical and intellectual quests. In other words, the narrator constellates Japan, whaling in general, and Moby Dick in particular within clustered images of danger, seductive mystery, and frustrating impenetrability. "Yes, there is death in this business of whaling - a speechlessly quick chaotic bundling of a man into Eternity," Ishmael reminds his readers (p. 37). Yet a compulsion to understand the "overwhelming idea of the great whale himself," a desire driven by

\footnotetext{
${ }^{3}$ See Sister M. Blish, "Melville and the Sea Drifters of Japan," Melville Society Extracts 76 (February 1989): 14-16, for an interesting suggestion about how an American whaler could have come by Japanese lumber for masts.
} 
his "everlasting itch for things remote," pulls at him. Remoteness acquires a geographical, as well as an intellectual, dimension when he notes, "I love to sail forbidden seas, and land on barbarous coasts" (p. 7). Ishmael's obsession is mirrored in that of a country so tantalized by Japan's exotic riches that it braved the perils lingering off its shores.

In 1846, Commodore James Biddle sailed into the far reaches of the Pacific with a letter from President James K. Polk proposing a treaty of commerce with Japan. He was rebuffed: "According to Japanese laws, the Japanese may not trade except with the Dutch and Chinese. It will not be allowed that America make a treaty with Japan or trade with her, as the same is not allowed with any other nation ... therefore you must depart as quickly as possible, and not come any more to Japan." ${ }^{2}$ Failure to heed their warnings resulted in physical violence. Biddle was literally shoved back into his own boat when he attempted to board a Japanese barge. Also receiving harsh treatment were shipwrecked whalers. In 1846,

the ship Lawrence had been wrecked near the coast, and the second mate and seven men, after landing, had been treated with great cruelty. One of the number had been tortured to death. The crew of the Lagoda, of New Bedford, that stranded on that coast at about the time of the loss of the Lawrence, were also tortured, and one of these men killed himself to escape further torment. The terrors that awaited all who might be cast away in Japanese waters were known to the whalemen who sailed to those waters. ${ }^{5}$

More fortunate castaways were denied proper clothing and forced to endure imprisonment in filthy, lice-infested cages. ${ }^{6}$ When reports of this cruel treatment were received in the United States, its citizens collectively imagined Japan as a harsh, threatening, impenetrable land.

In figuring Ishmael's obsessive hunt for the whale's meanings in terms of Japan, then, Melville infuses the timeless quest at

${ }^{4}$ James Murdoch, A History of Japan, 3 vols. (London: Kegan Paul, 1926), 3:570.

5John R. Spears, The Story of the New England Whalers (New York: Macmillan, 1908), pp. 146-47.

${ }^{6}$ Peter Booth Wiley, Yankees in the Lands of the Gods: Commodore Perry and the Opening of Japan (New York: Viking, 1990), pp. 24, 35. 
the heart of his novel with contemporary cultural significance. Ishmael has an overwhelming desire to embrace the unknown, but he also recognizes the danger of drawing too near the "ungraspable phantom." Commodore Matthew Perry had the same concern about approaching Japan: "It is said that a current setting to the north and east is continually in motion throughout the year. An expression of the islanders is that it always goes toward Japan and never comes back."7 Perry's passage echoes and inverts Ishmael's warning about the safety of the "insular Tahiti" with which he concludes his meditation in "Brit" (chap. 58): "For as this appalling ocean surrounds the verdant land, so in the soul of man there lies one insular Tahiti, full of peace and joy, but encompassed by all the horrors of the half known life. God keep thee! Push not off from that isle, thou canst never return!" (p. 274). Nor could Japanese sailors who drifted off course and were rescued by foreigners expect ever again to be free in their homeland: "they were imprisoned or even killed lest any foreign influence be introduced into the country."

Despite Japan's mysteries, its dangers are quite specific. In fact, the first death associated with a sperm whale in MobyDick is explicitly linked to Japan. The third memorial tablet Ishmael examines in Father Mapple's chapel commemorates

$$
\begin{gathered}
\text { The late } \\
\text { CAPTAIN EZEKIEL HARDY } \\
\text { Who in the bows of his boat was killed by a } \\
\text { Sperm Whale on the coast of Japan. } \\
\text { [P. 36] }
\end{gathered}
$$

While the other two tablets memorialize whalemen lost at sea or "towed out of sight by a Whale" (p. 35) -two forms of death common among whalemen which presage events aboard the Pequod-it is this third tablet that most ominously anticipates the final tragedy of the Pequod. The old Gay-Head Indian echoes both the location and danger foretold in the memorial tablet when he recounts the story of Ahab's original trauma: "he 
was dismasted off Japan" (p. 124). Moreover, the Japanese whaling ground is also the site of every other death, save Bulkington's, in Ishmael's narrative. Captain Gardiner's son, the Rachael's other men, and the Pequod's entire crew, save Ishmael, all perish "off Japan."

The omens accumulate. "The first man of the Pequod that mounted the mast to look out for the White Whale, on the White Whale's own peculiar ground [the Japanese grounds]; that man was swallowed up in the deep" (p. 524). Ishmael also associates Japan with another, powerful source of fear among whalers: "in these resplendent Japanese seas the mariner encounters the direst of all storms, the Typhoon" (p. 503), a phenomenon that had gathered into itself oft-cited connotations of Death and Judgment. The crew of the Pequod, of course, has particular cause to worry, for it was a "typhoon off Japan" that had earlier dismasted not only Ahab but his vessel. Thus superimposed on Ahab's maniacal hunt are all of the well-known vicissitudes of a voyage into Japanese waters.

A threat more unrelenting and predictable, however, is posed by the very object being pursued. The chapter "The Affidavit" is littered with the flotsam and jetsam of stove ships and gashed bodies, devastation wreaked by angered sperm whales. "Not a gallon [of lamp oil] you burn, but at least one drop of man's blood was spilled for it," Ishmael reflects (p. 206). Continually complicating the distinction between the slaughter and the study of whales, Ishmael further warns those who would too closely examine their bodies. Near the conclusion of "The Fountain," he suggests that it is not

at all prudent for the hunter to be over curious touching the precise nature of the whale spout. It will not do for him to be peering into it, and putting his face in it. ... For even when coming into slight contact with the outer, vapory shreds of the jet, ... your skin will feverishly smart, from the acridness of the thing so touching it. And I know one, who coming into still closer contact with the spout, whether with some scientific object in view, or otherwise, I cannot say, the skin peeled off from his cheek and arm. Wherefore, among whalemen, the spout is deemed poisonous; they try to evade it. Another thing; I have heard it said, and I do not much doubt it, that if the jet is fairly 
spouted into your eyes, it will blind you. The wisest thing the investigator can do then, it seems to me, is to let this deadly spout alone. [P. 373]

Like Japan, the whale is a mystery that, if too ardently pursued, will end in death or disfigurement.

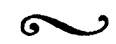

In much the way Ishmael longs to understand the whale, his culture craved Japan-desirous of its riches and curious about its mysteries but cautious of its dangers. As the Pequod enters the Pacific Ocean, Ishmael rhapsodizes:

The same waves wash the moles of the new-built Californian towns, but yesterday planted by the recentest race of men, and lave the faded but still gorgeous skirts of Asiatic lands, older than Abraham; while all between float milky-ways of coral isles, and low-lying, endless, unknown Archipelagoes, and impenetrable Japans. [Pp. 482-83]

The narrative regularly deploys such terms as "unknown," "impenetrable," and "milky-ways," all remote and all unreachable, in connection with Japan. On one occasion, Ishmael even expands his context to include the entirety of Asia-“"a vast-walled empire." I. A. Goncharov, a Russian novelist accompanying his country's thwarted trade mission to Japan in 1853, evokes the same qualities of danger, seduction, mystery, and entrapment with which Melville's fictional narrator characterizes the islands: "we approached [Japan] with rather anxious hearts; I at least had a heavy feeling as if I were going to jail even though the prison might be surrounded by trees." In an earlier entry, however, his vessel is still sufficiently distant that eagerness has yet to be converted into anxiety: "at last the aim of our ten months' voyage is achieved. Here is the locked box with the lost $k e y$, the country which foreigners have been trying to get acquainted with for so long - with futile efforts, with persuasion, with gold, with weapons and cunning politics." When his writ-

9“I. A. Goncharov's Account of Russia's Attempt to Open Japan in 1853," trans. Kathleen Price, in Center for Japanese Studies Occasional Papers, no. 2 (Ann Arbor: University of Michigan Press, 1952), pp. 3, 2; emphasis added. 
ten inquiries about population statistics are not adequately answered, however, Goncharov despairs of ever securing useful information from the Japanese:

What a people! ... What a system of guarding against contraband of all kind. What hope does it seem there could be for trade, for the introduction of Christianity, for enlightenment, when the building is so securely locked and the key has been lost. How and when will all this come? But come it will, there is no doubt, although not soon. ${ }^{10}$

For all the fear and frustration, then, the West was not prepared to give up on Japan. Indeed, it had coveted the island's real and anticipated riches since the late eighteenth century. In 1832, after some early failures, the United States renewed attempts to establish commercial relations with Japan. ${ }^{11}$ Trade was not the only motivation. The Pacific Mail Steamship Company, interested in running a steamer line from California to Shanghai, looked to Japan as a site for replenishing fuel and supplies. At the same time the whaling industry, its stocks having been depleted in the Atlantic in the 1820s, was searching for new, fertile fishing grounds; of the five recently discovered, the most productive was off Japan. ${ }^{12}$ When reports of its bounties reached whalemen in Canton, Captain Frederick Coffin of Nantucket piloted the British-owned Syren toward the islands' waters in what has been called "a long race [for] a prize that might excite the ambition of any yachtsman." One of the first two ships to reach the grounds, the Syren returned to London in 1826 with 2,768 barrels of sperm oil, the largest cargo ever brought into England. ${ }^{13}$

Throughout the 1830s and 40s, Nantucket and New Bedford whaling men invested heavily in the Northern Pacific (\$17 mil-

\footnotetext{
${ }^{10}$ George Alexander Lensen, Russia's Japan Expedition of 1852-1855 (Gainesville: University of Florida Press, 1955), p. 113. The adventurer Ranald MacDonald, who in 1848 asked to be set adrift so that he might enter Japan alone, noted that his captors told him nothing about Japan. His assigned companion, Tangaro, secretly brought him a map to view briefly, protesting that this "was a dangerous move since all Japanese are warned against providing any barbarians who landed with information about Japan" (Wiley, Yankees in the Lands of the Gods, pp. 21, 19, 14).

${ }^{11}$ Murdoch, History of Japan, 3:569.

${ }^{12}$ Wiley, Yankees in the Lands of the Gods, pp. 39-40, 30.

${ }^{13}$ Spears, New England Whalers, p. 153.
} 
lion in 1851). From Japan they needed security, and they needed a supply base. As President Millard Fillmore put it in his letter to the Japanese emperor,

Many of our ships pass every year from California to China; and great numbers of our people pursue the whale fishery near the shores of Japan. It sometimes happens, in stormy weather, that one of our ships is wrecked on your imperial majesty's shore's. In all such cases we ask, and expect, that our unfortunate people should be treated with kindness, and that their property should be protected, till we can send a vessel and bring them away. ... We [also] wish that our steamships and other vessels should be allowed to stop in Japan and supply themselves with coal, provisions, and water. ${ }^{14}$

Japan would eventually succumb to Fillmore's urgings (although not while he still remained in office), but while Melville was writing Moby-Dick, it remained isolated, refusing all requests for access to its coast for victualing and refitting whaling ships. James A. Williamson indicates the tension Japan's resistance created: "there was a blank area in the growing frequentation of the Pacific. It could not endure."15 Melville's midcentury contemporaries had said as much. As Goncharov noted in his journal, "indeed Japan remains almost the only gap in our knowledge of the geography and statistics of the settled areas of the globe."16

Japanese isolation could not endure, and it did not: Commodore Perry's fleet forced its way into the country in 1853, winning its concessions in 1854 . But prevailing attitudes that Japan was impervious and mysterious were not quickly altered. As a captain's clerk on board the Mississippi, one of the steam frigates in Perry's expedition, remarked upon entering Japanese waters, "we felt as if we had arrived at the outer door of the hermetic empire."17 Perry himself acknowledged the enigma of Japan in his journal: "the track taken by the squadron east of

\footnotetext{
${ }^{14}$ Arthur Walworth, Black Ships Off Japan: The Story of Commodore Perry's Expedition (New York: Knopf, 1946), p. 250.

${ }^{15}$ James A. Williamson, Cook and the Opening of the Pacific (London: Hodder \& Stoughton, 1946), p. 237.

${ }^{16}$ Goncharov, “Account of Russia's Attempt," p. 2.

${ }^{17}$ Wiley, Yankees in the Lands of the Gods, p. 164.
} 
the chain of islands which stretch from Formosa to Lew Chew [Okinawa] and from thence to Japan ... has rarely been traversed by the ships of modern nations, and the islands on the east side of the Chain are unknown to our present navigators."18 Ishmael infuses his discursive representation with his era's figures of Japan as a dangerous blank spot in the Pacific and as a rich, though hermetic, space. Japan, apparently like Queequeg's Kokovoko, although certainly a "true place," was not yet on any map.

Pockets of emptiness, blankness, or mystery appear throughout Moby-Dick and gather the narrative's enigmas, like the spirit spout, the albatross, Fedallah (and to some extent Queequeg), and, of course, Moby Dick. When discoursing on the whiteness of the whale, Ishmael observes, "in essence whiteness is not so much a color as the visible absence of color, and at the same time the concrete of all colors; it is for these reasons that there is such a dumb blankness, full of meaning, in a wide landscape of snows-a colorless, all-color of atheism from which we shrink" (p. 195). Ultimately, the white whale typifies the blankness that, despite painstaking cetological examination, can never be fully known.

That which is hidden is, of course, at once fascinating and frightening. In most cases, the promise of meaning or riches lurking beyond familiar boundaries is an irresistible invitation to penetrate the unknown, even if it involves such obvious risks as the whale's spout. Throughout the novel, blankness and absence paradoxically conceal a rich presence-a cask, a whale's head, a cavity containing ambergris, the Japanese islands harboring needed provisions and barely imagined cultural wealth, or a mad hunch regarding the absolute, all waiting to be mined.

Until the enigmatic object or presence emerges from behind its veil of blankness, it remains remote, uncertain, "other." In Moby-Dick both the whale and Japan partake of those characteristics. For instance, Ishmael mentions Volcano Bay on the

\footnotetext{
${ }^{18}$ Matthew C. Perry, The Japan Expedition, 1852-1854: The Personal Journal of Commodore Matthew C. Perry, ed. Roger Pineau (Washington: Smithsonian Institution Press, 1968), p. 88.
} 
Japanese coast when discussing the difficulty of finding the elusive white whale, and he reminds us of Japan's remoteness when he comments on Ahab's plan to "sweep inshore by the Philippine Islands, and gain the far coast of Japan, in time for the great whaling season there" (p. 381). While Japan may be literally far at this point in the narrative, the seemingly gratuitous reminder of distance enhances the thematic contribution of Japan as unapproachable or unknown, especially in comparison to the Philippines, about which Ishmael indicates some depth of knowledge when he expounds upon the advantages of Manila rope (p. 278). Later, he implies the complexity of trying to approach Japan when he alludes to Coffin's prosperous foray into its waters: a British whaleship was sent "on a testing cruise to the remote waters of Japan. That ship-well called the 'Syren'-made a noble experimental cruise; and it was thus that the great Japanese Whaling Ground first became generally known" (p. 444).

Elsewhere, Ishmael underscores the otherness of both Moby Dick and Japan by emphasizing their mysteries. In the chapter "Ahab's Boat and Crew, Fedallah," for example, Ishmael refers to the secret crew as "subordinate phantoms," that is, phantoms who will lose their strangeness with time and proximity:

Besides, now and then such unaccountable odds and ends of strange nations come up from the unknown nooks and ash-holes of the earth to man these floating outlaws of whalers; and the ships themselves often pick up such queer castaway creatures found tossing about the open seas on planks, bits of wreck, oars, whale-boats, canoes, blownoff Japanese junks, and what not. [Pp. 230-31]

The inclusion of Japanese junks within this catalogue of the bizarre serves to intensify its mysteriousness, as do Japanese allusions in the description of Fedallah's temperament: ${ }^{19}$

He was such a creature as civilized, domestic people in the temperate zone only see in their dreams, and that but dimly; but the like of

\footnotetext{
${ }^{19}$ See Katherine Plummer, The Shogun's Reluctant Ambassadors: Sea Drifters (Tokyo: Lotus, 1984) for a detailed discussion of the "sea drifters" and their impact on Japanese relations with the West.
} 
whom now and then glide among the unchanging Asiatic communities, especially the Oriental isles to the east of the continent-those insulated, immemorial, unalterable countries, which even in these modern days still preserve much of the ghostly aboriginalness of earth's primal generations. [P. 231]

The characterization of Japan as "insulated, immemorial, and unalterable" parallels that of the whale, which Ishmael describes as unchanging from the oldest recording of its existence, as well as that of Moby Dick, who, according to some whalemen, is both ubiquitous and immortal.

Perhaps the best expression of the seductive mystery driving Ishmael's entire project falls in the chapter "The Spirit-Spout." Appropriately, it is the enigmatic Fedallah who first sights the white whale's spout: "Lit up by the moon, it looked celestial; seemed some plumed and glittering god uprising from the sea" (p. 232). Although night hunting is unheard of, the crew, as if hypnotized by the sirens' song, is overwhelmed with a desire to apprehend the animal: "For though it was a most unwonted hour, yet so impressive was the cry, and so deliriously exciting, that almost every soul on board instinctively desired a lowering" (p. 233). Appearing only at night, the creature would not offer them the satisfaction; instead, it "mysteriously jetted into the clear moonlight, or starlight, as the case might be; disappearing again for one whole day, or two days, or three; and somehow seeming at every distinct repetition to be advancing still further and further in our van, this solitary jet seemed for ever alluring us on" (p. 233). Yet, in each manifestation of the quest for the "spirit-spout," danger lurks: "For a time, there reigned, too, a sense of peculiar dread at this flitting apparition, as if it were treacherously beckoning us on and on, in order that the monster might turn round upon us, and rend us at last in the remotest and most savage [i.e., Japanese] seas" (p. 233). Part of the danger arises from the unknowing embodied in the image that appears then vanishes; its fleeting quality and preternaturalness function as a suitable overture for what the crew finds in Moby Dick as well as the traits which color Ishmael's description of Japan. 
As the Pequod enters the Pacific Ocean, Ishmael continues to use Japan both geographically and metaphorically to mystify the location and establish it, like the white whale, as a narrative element drawing the ship to its doom. After exploding at Starbuck and dismissing him from his cabin, Ahab returns to his maps to plot his course into Japanese waters. In his "shrine," he stands mesmerized before the map of Japan, caught in the throes of an obsession that blinds him to the Pequod's other serious concerns.

The approach to Japan Ishmael figures as inexorable and predetermined: "Launched at length upon these almost final waters, and gliding towards the Japanese cruising-ground, the old man's purpose intensified itself. His firm lips met like the lips of a vice; the Delta of his forehead's veins swelled like overladen brooks; in his very sleep, his ringing cry ran through the vaulted hull, 'Stern all! The White Whale spouts thick blood!'” (p. 483). Powered on by Ahab's surging monomania, "penetrating further and further into the heart of the Japanese cruising ground, the Pequod was soon all astir in the fishery" (p. 491). As they encounter more whales, the crew becomes more thoroughly entangled in Ahab's obsession, until finally they face the dual mysteries-Moby Dick and Japan. Having brushed up against the "ungraspable phantom of life," they meet their doom.

\section{$\sim$}

"The ungraspable phantom of life" is, of course, Ishmael's phrase, not Ahab's. It is he, after all, who figures Japan as a geopolitical homology of the great white whale, both during and subsequent to his voyage aboard the fated Pequod. Ishmael rather than Ahab, in other words, offers Japan as a subtle equivalent for the philosophical, epistemological, and commercial richness, as well as the destructive potential, of the grand hooded phantom, Moby Dick. By virtue of this doubling, we argue, the same intensity, the same hyperbole, the same celebratory tones that charge Ishmael's commentary on whaling also inform his thinking about Japan. 
Many readings of Ishmael regard his philosophical questioning as a potential, sometimes a potent, alternative to Ahab's "quenchless feud"; correspondingly, the relative commercial failure of Melville's book is attributed to its unflinching repudiation of Western values. In writing Moby-Dick, James Barbour contends, Melville had "looked too deeply into the dark nature of existence and had spoken unacceptable truths to a conventional world." ${ }^{20}$ While such a view may serve general purposes, like addressing the critical reception of Moby-Dick, it is not sufficiently complex to characterize Ishmael's fascination with Japan and his purposive mystification of it. In other words, Ishmael betrays, we contend, a fascination with one dimension of an American expansionism he otherwise abhors. Insofar as he privileges the industry of whaling, then, he too, like Ahab, not in contrast to him, looks toward a future in which America dominates the globe.

Ishmael's account of the honorable and glorious history of whaling and his expectations for its continued role are marked by a bravado and hyperbole that contradict his caution and admittedly limited understanding of the whale as a philosophical and spiritual enigma. Celebrating the hardihood and bravery of Nantucketers, he muses:

What wonder, then, these Nantucketers, born on a beach, should take to the sea for a livelihood! They first caught crabs and quohogs in the sand; grown bolder, they waded out with nets for mackerel; more experienced, they pushed off in boats and captured cod; and at last, launching a navy of great ships on the sea, explored this watery world; put an incessant belt of circumnavigations round it; peeped in at Bhering's Straits; and in all seasons and all oceans declared everlasting war with the mightiest animated mass that has survived the flood. ...

And thus have these naked Nantucketers, these sea hermits, issuing from their ant-hill in the sea, overrun and conquered the watery world like so many Alexanders; parcelling out among them the Atlantic, Pacific, and Indian oceans, as the three pirate powers did

\footnotetext{
${ }^{20} \mathrm{James}$ Barbour, “All My Books Are Botches': Melville's Struggle with The Whale," in Writing the American Classics, ed. James Barbour and Tom Quirk (Chapel Hill: University of North Carolina Press, 1990), p. 25.
} 
Poland. Let America add Mexico to Texas, and pile Cuba upon Canada; let the English overswarm all India, and hang out their blazing banner from the sun; two thirds of this terraqueous globe are the Nantucketer's. For the sea is his; he owns it, as Emperors own empires; other seamen having but a right of way through it. Merchant ships are but extension bridges; armed ones but floating forts. . . The Nantucketer, he alone resides and rests on the sea; he alone, in Bible language, goes down to it in ships; to and fro ploughing it as his own special plantation. There is his home; there lies his business, which a Noah's flood would not interrupt, though it overwhelmed all the millions in China. [P. 64]

Nantucketers evolve into whalemen according to a sort of Darwinian logic (although that theory had yet to enter the mainstream): first they caught crabs, then waded out for mackerel, and then pushed off for cod before finally realizing their potential in launching a navy to round the globe in search of the great leviathan. But as this aquatic agribusiness gains strength, greater militaristic power is required to sustain it-a navy of whale ships, belting the globe and declaring everlasting war against the denizens of the deep. They overran and conquered like so many Alexanders, and they parcelled out the sea after the fashion of pirates, reigning over their conquests like emperors over empires or masters over plantations.

The image of America's landlubbing and seafaring forces carrying their interests throughout the world was not simply a metaphorical relation for Senator William Gilpin. In 1846, Gilpin referred to the whaling fleet as the maritime arm of America's "pioneer army":

The men of these two great enterprises of which we have spoken may not be thwarted. The ambition of the one incarcerates him in the womb of a ship, to pursue over the boundless ocean and through exciting dangers the capture of the salt sea-monster; his spoil is blubber; oil illumes the long night of his home, ivory rolls over the billiard table, and whalebone bends to the fancies of female taste. The other rescues the wilderness from savage masters and idle nature. . . In both burns the glorious genius of enterprise, commingled of virtue and valor. . . . Together, side by side, linked in the freshness of the 
bridal hour, let them tread onward their wedded and indissoluble career. ${ }^{21}$

While the whalemen make war on the leviathan, however, they have a conciliatory effect on international relations. In "The Advocate," Ishmael boasts:

I freely assert, that the cosmopolite philosopher cannot, for his life, point out one single peaceful influence, which within the last sixty years has operated more potentially upon the whole broad world, taken in one aggregate, than the high and mighty business of whaling. ... It would be a hopeless, endless task to catalogue all these things. Let a handful suffice. For many years past the whale-ship has been the pioneer in ferreting out the remotest and least known parts of the earth. ... If American and European men-of-war now peacefully ride in once savage harbors, let them fire salutes to the honor and the glory of the whale-ship, which originally showed them the way, and first interpreted between them and the savages. ...

Until the whale fishery rounded Cape Horn, no commerce but colonial, scarcely any intercourse but colonial, was carried on between Europe and the long line of the opulent Spanish provinces on the Pacific coast. It was the whaleman who first broke through the jealous policy of the Spanish crown, touching those colonies; and, if space permitted, it might be distinctly shown how from those whalemen at last eventuated the liberation of Peru, Chili, and Bolivia from the yoke of Old Spain, and the establishment of the eternal democracy in those parts.

That great America on the other side of the sphere, Australia, was given to the enlightened world by the whaleman. . . . The uncounted isles of all Polynesia confess the same truth, and do commercial homage to the whale-ship, that cleared the way for the missionary and the merchant, and in many cases carried the primitive missionaries to their first destinations. If that double-bolted land, Japan, is ever to become hospitable, it is the whale-ship alone to whom the credit will be due; for already she is on the threshold. [Pp. 109-10; emphasis added]

Even if we consider the possibility that Ishmael is being ironic, he nonetheless offers without comment a consensual vision of America's undeniable role in the world. Instrumental in exert-

\footnotetext{
${ }^{21}$ Quoted by James Duban, Melville's Major Fiction: Politics, Theology, and Imagination (DeKalb: Northern Illinois University Press, 1983), p. 86.
} 
ing all "peaceful influence," the whaling industry now ferrets out new geographic zones for exploration, "opens" them up for "American and European men-of-war" (which can now "peacefully ride in once savage harbors"), "breaks up" the jealous Spanish monopoly of these markets, and "clears" the way for religion and commerce. Imaged here is a barely suppressed bellicosity itself reinterpreted as preeminently a mission of domestication and pacification. Even "remote" and "double-bolted" Japan will soon find itself extending its hospitality and opening itself to Western interests.

Ishmael's discourse on the "high and mighty business of whaling" gathers its energies from the divinely appointed rights propounded by adherents of Manifest Destiny, many of whom saw Japan as the final barrier to the globalization of whaling and mercantile markets. David Porter, "America's first naval imperialist," anticipates that agenda in an 1815 letter to President James Madison. In his call for a governmentally supported mission to open up the Pacific, especially Japan, to the United States, Porter balances a variety of rhetorical strategies. Passages stressing the value of "enlarging the bounds of science, adding to the knowledge of men" recall Ishmael's unflagging belief in the vital importance of abstract knowledge. Porter's express desire "of serving [his] country, and of using every effort for her honor and glory," his confident reminder that "we, Sir, are a great and rising nation," and his regret that "even the Dutch and Portuguese have shewn a degree of enterprize which has not been equalled by us" display his patriotic credentials. It is from a "manly" posture, however (explicitly contrasted to "a want of manly dignity on the part of the [American] negotiators"), that he finally presses his proposal to launch the mission: "the time may be favorable, and it would be a glory beyond that acquired by any other nation for us, a nation of only 40 years standing, to beat down their [Japanese] rooted prejudices, secure to ourselves a valuable trade, and make that people known to the world." 22 It is a posture struck again and again whenever the topic emerges in the national conversation.

$\rightarrow{ }^{-2}$ Allan B. Cole, ed., "Captain David Porter's Proposed Expedition to the Pacific and Japan, 1815," Pacific Historical Review 9 (1940): 62-65, emphasis added. 
The internal correspondence prior to Commodore Perry's departure for the Pacific reveals a barely restrained contempt for the Japanese and their hazily conceived customs. In his 1852 annual report, John P. Kennedy, secretary of the navy, noted that in Japan Western sailors had suffered at the hands of "a weak and semi-barbarous people." Having thus racialized the Japanese, Kennedy felt justified in belligerently defending U.S. penetration into Japan (and the rest of Asia): "Christendom is constrained by the pressure of an increasing necessity, to publish its wants and declare its rights to the heathen, and in making its power felt will bring innumerable blessings to every race which shall acknowledge its mastery."23

President Fillmore's letter to the Japanese is replete with gestures of friendship, respect, and solicitude as well as descriptions of the mutually desirable benefits that will naturally flow from a successfully concluded treaty. Perry's letter, however, adds some bite. Rather like "the universal cannibalism of the sea" lurking under the Pacific's "loveliest tints of azure" in Ishmael's meditation in "Brit," the threat of armed, naval intervention lurks barely beneath the surface of Perry's polite, diplomatic prose.

The undersigned holds out all these arguments in the hope that the Japanese government will see the necessity of averting unfriendly collision between the two nations, by responding favorably to the propositions of amity, which are now made in all sincerity.

Many of the large ships-of-war destined to visit Japan have not yet arrived in these seas, though they are hourly expected; and the undersigned, as an evidence of his friendly intentions, has brought but four of the smaller ones, designing, should it become necessary, to return to Yedo in the ensuing spring with a much larger force.

But it is expected that the government of your imperial majesty will render such return unnecessary, by acceding at once to the very reasonable and pacific overtures contained in the President's letter, and which will be further explained by the undersigned on the first fitting occasion.

${ }^{23}$ Congressional Globe, 32d Cong., 2d sess., app., p. 9, 4 December 1852. For a thorough discussion of the racialized discourse of mid-century manifest destiny, see Reginald Horsman, Race and Manifest Destiny: The Origins of American Racial Anglo-Saxonism (Cambridge: Harvard University Press, 1981). 
With the most profound respect for your imperial majesty, and entertaining a sincere hope that you may long live to enjoy health and happiness, the undersigned subscribes himself, M. C. Perry. ${ }^{24}$

Perry, moreover, could count on more than his own fleet. Numerous communiqués explicitly reminded the Japanese that growing technological superiority (specifically steamships) and increasing cooperation among nations of the West were irresistible. It was only a matter of time, for time and God were on the side of the Americans.

Insofar as it inhabits, and occasionally drives, the discourse of someone like Ishmael, whose primary interests are clearly focused elsewhere, the rhetoric of expansionism is revealed for what it was at the time: a pervasive ideology. Even the bawdy humor of the chapter "Fast Fish and Loose Fish" (perhaps especially such humorous interludes) is overwhelmed by expansionist rhetoric when it branches into such highly politicized questions as "what was America in 1492 but a Loose-Fish, in which Columbus struck the Spanish standard by way of waifing it for his royal master and mistress? What was Poland to the Czar? What Greece to the Turk? What India to England? What at last will Mexico be to the United States?" (p. 398). And what the land of the rising sun? Adding its name to the list of "Fast Fish" is but a successful trade mission or military urge away.

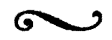

Melville scholars have frequently characterized the relationship between Ishmael and Ahab as roughly approximating the tension between knowledge and power. Whereas Ishmael longs to understand the whale, Ahab wants only to destroy it. In the end, however, such a neat distinction may not be fully justified. Ishmael's classification and historicization of whales and cetological lore, in other words, is inseparable from the cutting in and trying out of whale flesh. The blood and guts business of whaling and its "crude" economic dimension exist alongside Ahab's spiritual agony as well as the philosophical, psychologi-

${ }^{24}$ Walworth, Black Ships Off Japan, pp. 252-53. 
cal, and stylistic imperatives of Ishmaelean voyaging. Both Ahab's and Ishmael's insistence that meaning lurks behind, beneath, or above the realm of economic activity is a necessary, albeit desperate, metaphysical rationale for expanding global markets. To be sure, Ishmael remains intrigued by the mysteries of the white whale - and of its narrative potential. It is quite possible, however, that he is equally invested in the commercial potential of the black ships that finally and forever open Japan to the West. ${ }^{25}$

${ }^{25}$ The black ships were so called not only for the sooty black smoke the steamers belched out but for the ominous opening up of Japan they signaled. As recently as 1988, Clyde V. Prestowitz, Jr., a former trade negotiator for the United States, could still reflect on the ramifications of that day in 1853: "the memory of those ships-known as the 'black ships' because of both their color and their impact-is forever etched into Japan's psyche" (Trading Places: How We Allowed Japan to Take the Lead [New York: Basic, 1988], p. 105). See also Wiley, Yankees in the Lands of the Gods, esp. chap. 15, "The Black Ship Metaphor, The Second Opening of Japan, and Global Hegemony," for an excellent analysis of the contemporary implications of the West's incursions into Japanese social, economic, and cultural life.

Russell Reising is Professor of American literature and culture and Chair of the Department of English at the University of Toledo. His most recent book, LOOSE ENDS: CLOSURE AND CRISIS IN THE AMERICAN SOCIAL TEXT (1997), includes a chapter on Melville's novel ISRAEL POTTER: HIS FIFTY YEARS OF EXILE.

Peter J. Kvidera, a doctoral candidate at the University of Washington, is working on a dissertation that explores literary representations of Americanization in late-nineteenth- and early-twentieth-century American immigrant narratives. 